\title{
Attention-Deficit Hyperactivity Disorder
}

\author{
BD Gupta ${ }^{1 *}$, Pankaj Agrawal ${ }^{2}$ and RK Maheshwari ${ }^{3}$ \\ ${ }^{1} S N$ Medical College, India \\ ${ }^{2}$ Navjeevan Hospital, India \\ ${ }^{3}$ Med \& Hlth (Retd), India
}

Submission: July 05, 2017; Published: July 31, 2017

*Corresponding author: Gupta BD, SN Medical College, 120, Bhagat ki kothi Ext. Pali Road, Jodhpur, India, Tel: 0291-2724255; Fax: 09460767958; Email: brahmadgupta@hotmail.com

Abstract

ADHD is the most common neuro-behavioral disorder of the child. The present review article summarizes various aspects of its etiology, symptomatology, diagnostic methods, and various aspects of management. The disease need to be treated by a inter-disciplinary team including pediatricians, psychologists, sociologists etc and there is need to involve parents, school staff and if possible the children himself and must be based around the establishment of good working relationships with family and school.

\section{Introduction}

Attention-deficit/hyperactivity disorder (ADHD), a multidimensional syndrome is the most common behavioural disorder of children [1], characterized by symptoms of inattention, impulsive behaviour and hyperactivity resulting in behavioral problems and poor academic performance. The hallmark of ADHD is problem of sustaining inhibition (a mental process that restrains an action, behaviour or emotion) rather than sustaining attention.

\section{Prevalence and Epidemiology of ADHD}

Prevalence of ADHD among school-aged children in different studies varies between $5-12 \%[2,3]$, and the disorder is reported to decline with increasing age [4]. Boys are 2.4-4 times more likely to have the illness than girls. The disorder is found in all cultures, and is known to persist into adulthood. The overall prevalence in adults is about $4.4 \%$. About $35-65 \%$ of ADHD children will continue to have the disorder in adulthood [5]. Of these, $15 \%$ will show no improvement in adult life, while the remainder will experience partial improvement [6].

\section{Etiology and Risk Factors}

The exact cause of ADHD is still an enigma. Many theories have been put forward to explain the syndrome viz. chemical (neurotransmitter) theory, frontal lobe disorder theory, genetic theory, environmental factors etc.

\section{Chemical (Neurotransmitter theory)}

Neurotransmitters (Nor epinephrine and dopamine) are used by the brain to stimulate or repress stimulation in brain cells. To pay proper attention, the brain must be adequately stimulated. To have proper control of our impulses, areas of the brain must be adequately controlled, repressed, or slowed down. In ADHD children, both systems of stimulation and repression are not working correctly. Some studies suggest that ADHD Children/Adults may have only ten to twenty-five percent of these two neurotransmitters found in the normal brain [7].

\section{Frontal lobe disorder}

Frontal lobe of brain is destined with planning and organizing different tasks. It controls many aspects of everyday life. This part of brain is involved in decision making, planning, error detection, resisting temptations and impulse control-these functions are also known as "executive functions". It has been observed that in children with ADHD, these "executive" areas of the brain are under-active. Moreover increasing activity in this area has been shown to decrease behavioural symptoms. A decreased frontal lobe mass has also been reported in these children [8-10].

\section{Genetic}

Since the disease is said to run in families, genetic factors are sure to be blamed. Genetic variation in dopamine receptor 
genes DRD4 and DRD5, have been consistently associated with ADHD [11]. Other genes were also linked to ADHD, such as the Dopamine Beta Hydroxylase gene (DBH), the glutamate receptor gene (GRM7), the serotonin transporter gene (5HTT), and the serotonin receptor 1B gene (HTR1B) [12].

\section{Environemental factors}

Role of environmental factors is uncertain; they may influence symptoms of ADHD (sub-syndromic) rather than the syndrome of ADHD [13]. Most of these factors, which are associated with ADHD, are pregnancy and birth related risk factors which are classified into three groups including prenatal, perinatal, and postnatal risk factors.

\section{Prenatal risk factors}

A large number of studies have shown that maternal exposure to alcohol, tobacco, and cocaine during pregnancy increases the risk of ADHD. Various studies have demonstrated that preeclampsia, maternal anemia, lower serum level of iron and iodine, and trauma to abdomen during pregnancy are associated with increased risk of ADHD development $[14,15]$.

\section{Perinatal risk factors}

A number of risk factors such as prematurity, low birth weight and breech delivery have shown consistent association with increased risk of ADHD [16].

\section{Postnatal risk factors}

Postnatal viral infections such as measles, varicella, and rubella increase the risk of developing ADHD. Additionally, several other factors such as breast-feeding, head injury in early childhood and adolescence, encephalitis, convulsion and endocrine disorder are estimated to be risk factors for development of ADHD [12]. Incidence of ADHD has been shown to be more common in children with lower rates of breast feeding [17].

\section{Other factors}

It has been observed that adverse family environment variables such as family conflict, decreased family cohesion, and exposure to maternal psychopathology, low social class, large family size, foster care placement increases the risk for developing ADHD [14]. Iron and zinc deficiency has also been implicated in ADHD, which is notable because both are required for the production of Nor Epinephrine and Dopamine [18].

\section{Symptoms and Diagnosis}

The diagnosis of ADHD is made by careful clinical history. Many-a-times it is difficult to differentiate between a normal and ADHD child. Since ADHD is a behavioural disorder hence there are hardly any positive physical findings. Similarly no laboratory investigation is available to confirm the diagnosis. Onset is usually before seven yrs of age. The child has an entirely different behaviour not primarily attributable to poor parenting, lack of discipline, low motivation etc. The abnormal behaviour is observed at several settings/situations. The features persist over time. The disturbance causes clinically significant distress or impairment in social, academic, or occupational functioning. Before labeling ADHD problems like sleep disorders, anxiety, depression, and certain types of learning disabilities must be excluded. Children with ADHD and with clinical features of autism should also receive genetic testing to rule out Fragile $\mathrm{X}$ syndrome [13]. It has to be kept in mind that every child that fidgets and/or behaves defiantly is not ADHD.

The child often fidgets or squirms about when seated, shifts rapidly from one task to another without completing first task or activity, speaks irrelevantly, out of turn or speaks excessively, does not listen, can engage in dangerous activities causing harm to himself/herself [7]. The neuro-behavioral disorder is marked by inattention, difficulty in controlling impulses and excessive motor activity. The child should be labeled as ADHD only if the symptoms persist for more than six months. There is no single test to iagnose ADHD, currently, there are two widely used diagnostic criteria for ADHD: the International Classification of Diseases (ICD) by WHO and the Diagnostic and Statistical Manual of Mental Disorders (DSM) by American Psychiatric Association. These scales include the Conners Index Questionnaire, and the Vanderbilt ADHD Diagnostic Teacher Rating Scale [13]. ICD10 uses the name "hyperactivity disorders" to emphasize the two major symptoms, attention disorder and hyperactivity (impulsivity), which occur simultaneously and in multiple occasions such as home and school. This standard excludes other mental dysfunctions including anxiety disorder, mood disorder, pervasive developmental disorder and schizophrenia.

\section{DSM-5 Criteria for ADHD}

People with ADHD show a persistent pattern of inattention and/or hyperactivity-impulsivity that interferes with functioning or development [19].

\section{Inattention}

Six or more symptoms of inattention for children up to age 16 , or five or more for adolescents 17 and older and adults; symptoms of inattention have been present for at least 6 months, and they are inappropriate for developmental level:

Often fails to give close attention to details or makes careless mistakes in schoolwork, at work, or with other activities.

1. Often has trouble holding attention on tasks or play activities.

2. Often does not seem to listen when spoken to directly.

3. Often does not follow through on instructions and fails to finish schoolwork, chores, or duties in the workplace (e.g., loses focus, side-tracked). 
4. Often have trouble organizing tasks and activities.

5. Often avoids, dislikes, or is reluctant to do tasks that require mental effort over a long period of time (such as schoolwork or homework).

6. Often loses things necessary for tasks and activities (e.g. school materials, pencils, books, tools, wallets, keys, paperwork, eyeglasses, mobile telephones).

7. Is often easily distracted

8. Is often forgetful in daily activities.

\section{Hyperactivity and impulsivity}

Six or more symptoms of hyperactivity-impulsivity for children up to age 16, or five or more for adolescents 17 and older and adults; symptoms of hyperactivity-impulsivity have been present for at least 6 months to an extent that is disruptive and inappropriate for the person's developmental level

\section{Hyperactivity}

i. Often fidgets with or taps hands or feet, or squirms in seat.

ii. Often leaves seat in situations when remaining seated is expected.

iii. Often runs about or climbs in situations where it is not appropriate (adolescents or adults may be limited to feeling restless).

iv. Often unable to play or take part in leisure activities quietly.

v. Is often "on the go" acting as if "driven by a motor".

vi. Often talks excessively.

\section{Impulsivity}

i. Often blurts out an answer before a question has been completed.

ii. Often has trouble waiting his/her turn.

iii. Often interrupts or intrudes on others (e.g., butts into conversations or games).

In addition, the following conditions must be met.

i. Several inattentive or hyperactive-impulsive symptoms were present before age 12 years.

ii. Several symptoms are present in two or more setting, (such as at home, school or work; with friends or relatives; in other activities).

iii. There is clear evidence that the symptoms interfere with, or reduce the quality of, social, school, or work functioning. iv. The symptoms are not better explained by another mental disorder (such as a mood disorder, anxiety disorder, dissociative disorder, or a personality disorder). The symptoms do not happen only during the course of schizophrenia or another psychotic disorder.

\section{Changes in the DSM-5}

The fifth edition of the DSM was released in May 2013 and replaces the previous version, the text revision of the fourth edition (DSM-IV-TR). There were some changes in the DSM-5 for the diagnosis of ADHD.

i. Symptoms can now occur by age 12 rather than by age 6.

ii. Several symptoms now need to be present in more than one setting rather than just some impairment in more than one setting.

iii. New descriptions were added to show what symptoms might look like at older ages.

iv. For adults and adolescents age 17 or older, only 5 symptoms are needed instead of the 6 needed for younger children.

\section{Types of ADHD}

Based on the types of symptoms, three kinds (presentations) of ADHD can occur

Combined Presentation (ADHD-C): If enough symptoms of both criteria inattention and hyperactivity-impulsivity were present for the past 6 months. CT represents the most common sub-population of ADHD patients, and has combined higher ODD, CD, anxiety and depression disorders, leading to social dysfunction and poor prognosis [20].

Predominantly Inattentive Presentation (ADHD-I): If enough symptoms of inattention, but not hyperactivityimpulsivity, were present for the past six months.

Predominantly Hyperactive-Impulsive Presentation (ADHD-HI): If enough symptoms of hyperactivity-impulsivity but not inattention were present for the past six months. Combined type ADHD had the highest rates of co-morbidity with oppositional defiant disorder as compared to the ADHD HI and ADHD-I. Studies have shown that there were poor academic scores, combined with anxiety and depression in PI type patients, which mainly consist of girls and adolescents. Children with HI type generally have no academic problems, but are more likely to be complicated with conduct disorder.

\section{Comorbidities}

It is well established that ADHD frequently is co-morbid with other psychiatric disorders like oppositional defiant disorder (ODD), conduct disorder (CD), substance abuse disorder, and anxiety disorder [20]. Depending on the precise 
psychometric definition, 25\%-35\% of patients with ADHD will have a coexisting learning or language problem [21]. Nearly onefourth of ADHD children have an associated learning disorder of reading, spelling, writing and arithmetic [18]. ADHD is also associated with academic underachievement and cognitive impairment from pre-school age to adulthood [18]. In addition, children with ADHD have several associated difficulties in various domains of functioning, including adult relationships (e.g., noncompliance with adult requests), school functioning (e.g. classroom disruption, poor achievement), and peer and sibling relationships (e.g. annoying, intrusive, overbearing, and aggressive behaviours) [18]. Children with ADHD have higher rates of tic disorders [21], which may contribute additional dysfunction due to distractions and social impairments directly attributable to the movements or vocalizations themselves.

\section{Treatment}

Management of ADHD is in fact an art. Patients must be managed by a team of doctors (pediatricians, psychologists, sociologists) with full involvement of parents. Both doctors and parents must understand that it's tough for the individual has to cope with daily frustrations. It's rough on family members whose lives are regularly disrupted by the disorganization, outbursts, temper tantrums or other misbehaviour of the child or teen. It's normal for parents to feel helpless and confused about the best ways to handle their child in these situations. Because kids with ADHD do not purposely decide to act up or not pay attention, traditional discipline-like spanking, yelling at, or calmly trying to reason with your son or daughter -usually doesn't work [22]. The Figure 1 depicts the algorithm which can be taken as guidelines by the treating team [13]. Hence, treatment should be under three heads and they can be given alone or in combination

i. Pharmacotherapy

ii. Psycho-therapy or behavioral therapy, and

iii. Educational interventions.

The initial focus of treatment is to reduce the core symptoms of ADHD. Medication is usually offered as first-line treatment for patients aged 6 years and over while non-pharmacological treatment, consisting primarily of parenting interventions that focus on behavioural management, is generally recommended for children under 6 years of age.

\section{Pharmacotherapy}

Psycho-stimulants are the first line drugs and are highly effective for $75-90 \%$ of children with ADHD. They consistently reduce ADHD core features [23]. They have their greatest effects on symptoms of hyperactivity, impulsivity, and inattention, and the associated defiance and aggression. They improve classroom performance and behavior and promote increased interaction. Yet, psycho-stimulants do not appear to change long-term outcomes such as peer relationships, social or academic skills, or school achievement [24]. The most common stimulant medications (amphetamines) are
a. Methylphenidate: MPH
b. MPH Transdermal Patch
c. Dexmethylphenidate
d. Oros-Methylphenidate
e. Dextroamphetamine
f. Pemoline
g. Lis-Dexamfetamine

Nonstimulant therapy: The only approved drug in this category includes atomoxetine. It is a nonselective noradrenaline reuptake inhibitor that results in increased synaptic noradrenaline. Atomoxetine is used in children with a failed stimulant trial as first line therapy due to untoward side-effects, e.g. mood fluctuations or tic disorders, or those with a history of substance abuse [21].

\section{Antidepressant treatment}

These drugs are used when drugs described above failed to deliver good results [22].

a. Buproprion hydrochloride-an antidepressant that is involved in the reuptake inhibition of dopamine and noradrenaline and potentiates dopaminergic neurotransmission. It decreases hyperactivity, aggression and conduct problems.

b. Imipramine or nortriptyline-these are tricyclic antidepressants which can improve hyperactivity and inattentiveness. They can be especially helpful in children experiencing depression or anxiety. During overdose, the tricyclic antidepressants have the highest risk of cardiovascular side-effects. Therefore, they should be the last line of therapy.

c. Clonidine hydrochloride-used to treat high blood pressure, clonidine also can help manage ADHD and treat conduct disorder, sleep disturbances or a tic disorder. Research has shown it decreases hyperactivity, impulsivity and distractibility, and improves interactions with peers and adults.

d. Guanfacine-this antihypertensive decreases fidgeting and restlessness and increases attention and a child's ability to tolerate frustration. Tenex is the short-term preparation, while Inuniv is the long-term preparation

Duration of treatment: As this disease is a chronic one lasting for years or for even lifetime, medications are to be given for a long time. Duration of therapy has to be individualized and parents must be explained in detail about the adverse effects of the drug. They must also be warned not to stop the drug without prior consultation (Table 1). 


\section{Global Journal of Intellectual \& Developmental Disabilities}

Table 1: Medications Used with Children with ADHD [18].

\begin{tabular}{|c|c|c|c|}
\hline Drugs & Total Daily Doses & Daily Doses Schedule & $\begin{array}{c}\text { Common Adverse Drug } \\
\text { Reactions }\end{array}$ \\
\hline \multicolumn{4}{|c|}{ Stimulants } \\
\hline Methylphenidate & $1-2 \mathrm{mg} / \mathrm{kg} /$ day & $1-3$ times & $\begin{array}{l}\text { Decreased appetite, insomnia, } \\
\text { cardiac adverse events }\end{array}$ \\
\hline Dextroamphetamine & $0.3-1 \mathrm{mg} / \mathrm{kg} /$ day & $2-3$ times & \\
\hline Methylphenidate patch & $10-30 \mathrm{mg} / 9$ hours & Daily & $\begin{array}{l}\text { 3-4 hours regular duration, } \\
\text { extended release for } 9 \text { hours }\end{array}$ \\
\hline Magnesium pemoline & $1-2.5 \mathrm{mg} / \mathrm{kg} /$ day & $1-2$ times & Rare, serious hepatotoxicity \\
\hline Modafinil & $200-400 \mathrm{mg}$ & Daily & $\begin{array}{l}\text { Narcolepsy, fewer } \\
\text { sympathomimetic effects than } \\
\text { amphetamines }\end{array}$ \\
\hline \multicolumn{4}{|c|}{ Non Stimulants } \\
\hline Atomoxetine & $0.5-1.4 \mathrm{mg} / \mathrm{kg} /$ day & 1-2times & $\begin{array}{l}\text { Appetite suppression, weight } \\
\text { loss, increased heart rate, blood } \\
\text { pressure, not abusable }\end{array}$ \\
\hline $\begin{array}{c}\text { Tricyclic antidepressants } \\
\text { Imipramine } \\
\text { Clomipramine } \\
\text { Despramine }\end{array}$ & $2-5 \mathrm{mg} / \mathrm{kg} /$ day & 1-2times/day & $\begin{array}{l}\text { Narrow therapeutic index, } \\
\text { overdoses can be fatal. } \\
\text { Anticholinergic side effects: dry } \\
\text { mouth, constipation, blurred } \\
\text { vision, weight loss }\end{array}$ \\
\hline $\begin{array}{c}\text { Clonidine (alpha } 2 \text { agonists) } \\
\text { Guanfacine }\end{array}$ & $\begin{array}{l}0.003-0.010 \mathrm{mg} / \mathrm{kg} / \text { day } \\
0.015-0.05 \mathrm{mg} / \mathrm{kg} / \text { day }\end{array}$ & $\begin{array}{l}2-3 \text { times } \\
1-2 \text { times }\end{array}$ & $\begin{array}{l}\text { Sedation, hypotension, dry mouth, } \\
\text { confusion, depression, rebound } \\
\text { hypertension, }\end{array}$ \\
\hline Propranolol (beta blocker) & $0.003-0.010 \mathrm{mg} / \mathrm{kg} /$ day & 2 times & $\begin{array}{l}\text { Risk of bradycardia and } \\
\text { hypotension and rebound } \\
\text { hypertension, bronchospasm }\end{array}$ \\
\hline
\end{tabular}

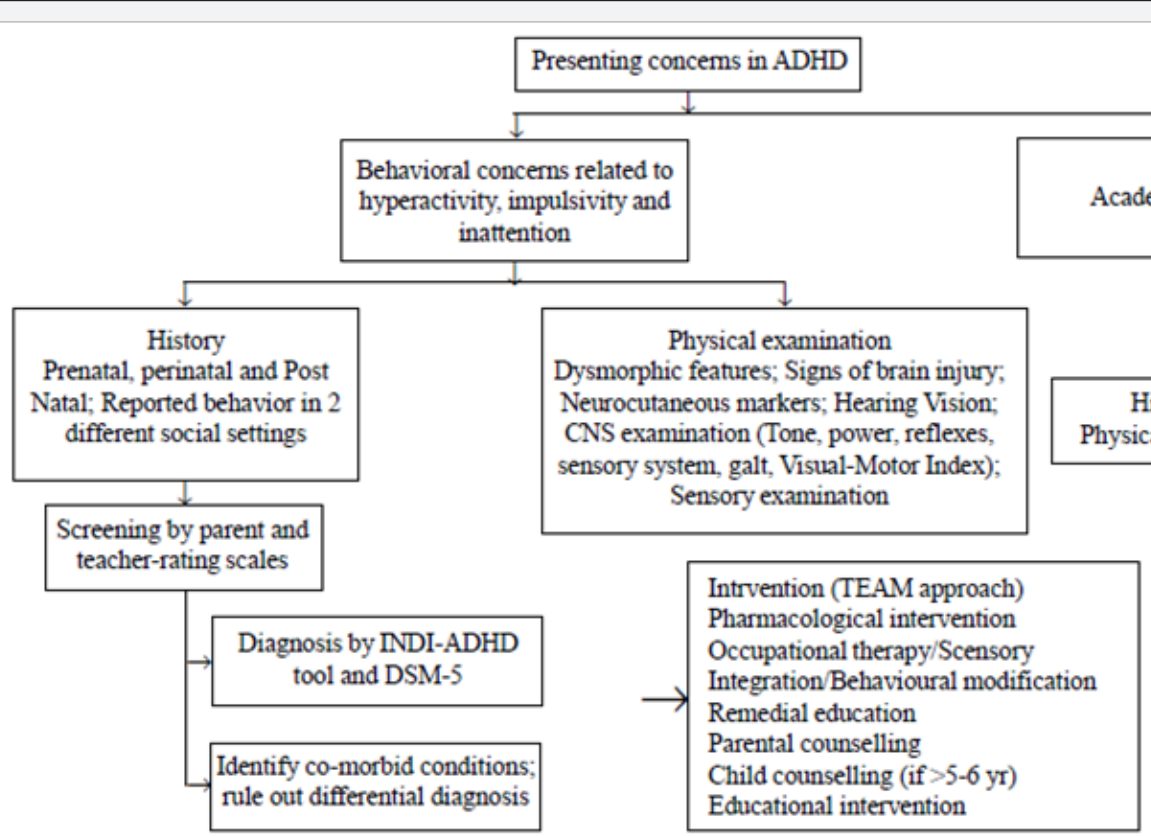

Figure 1: Flowchart for management of ADHD [13]. 


\section{Behavioral therapy}

Behavioural approaches represent a broad set of specific interventions that have the common goal of modifying the physical and social environment to alter or change behaviour. Behavioural therapy is a multi pronged approach including parents as well as a wide range of professionals, such as psychologists, school personnel, community mental health therapists, and primary care physicians and most importantly child himself. The hallmark of therapy is rewarding approach. The child's behaviour should be studied in detail and the team should choose a negative behaviour that needs change and a positive behaviour that should be allowed to continue [25]. For every positive response child should be rewarded, needless to say the reward must be as per the liking of the child and should be motivational. The plan designed must be individualized and should be changed if it fails to deliver. The school teachers and management also need to be educated about the disease and they should also be taught how to manage these child. Many a times it is better to form a group of parents of ADHD children [25]. Behavior therapy is best given by parents [26]. Older siblings can also be involved (Figure 1).

\section{Educational interventions}

Many-a-times the normal children may make a joke of the ADHD children making his treatment more worse. Hence, educational interventions also have a big role to play. Not only his class-mates be taken into confidence, there should also be classroom modification, proper accommodation, special attention from the school staff, personalized syllabus etc [13].

\section{References}

1. Barbara T, Jennifer G, Param K (2017) Dignosis and Management of ADHD in children. Am Fam Physician 90(7): 456-464.

2. Linnet KM, Dalsgaard S, Obel C, Wisborg K, Henriksen TB, et al. (2003) Maternal lifestyle factors in pregnancy risk of attention defcit hyperactivity disorder and associated behaviors: review of the current evidence. Am J Psychiatry 160(6): 1028-1040.

3. Grizenko N, Shayan YR, Polotskaia A, Ter-Stepanian M, Joober R (2008) Relation of maternal stress during pregnancy to symptom severity and response to treatment in children with ADHD. J Psychiatry Neurosci 33(1): 10-16.

4. Faraone SV, Sergeant J, Gillberg C, Biederman J (2003) Te worldwide prevalence of ADHD: is it an American condition? World Psychiatry 2(2): 104-113.

5. Biederman J, Faraone SV (2005) Attention-defcit hyperactivity disorder. Lancet 366(9481): 237-248.

6. Polanczyk G, Jensen P (2008) Epidemiologic Considerations in Attention Deficit Hyperactivity Disorder: A Review and Update. Child Adolesc Psychiatric Clin N Am 17(2): 245-260.

7. Gaynor M (2017) What is ADHD and how it is treated.
8. ADHD and Frontal Lobe Dysfunction.

9. (2017) Corey Leidenfrost ADHD \& the Frontal Lobe.

10. Shue KL, Douglas VI (1992) Attention deficit hyperactivity disorder and the frontal lobe syndrome. Brain Cogn 20(1): 104-124.

11. Biederman J, Faraone SV (2002) Current concepts on the neurobiology of attention-defcit/hyperactivity disorder. J Atten Disord 6(Suppl 1): S7-S16.

12. Faraone SV, Doyle AE, Mick E, Biederman J (2001) Meta-analysis of the association between the 7-repeat allele of the dopamine $D(4)$ receptor gene and attention deficit hyperactivity disorder. Am J Psychiatry 158(7): 1052-1057.

13. Dalwai S, Unni J, Kalra V, Pratibha S, Shrivastava L, et al. (2017) Consensus Statement of the Indian Academy of Pediatrics on Evaluation and Management of Attention Deficit Hyperactivity Disorder. Indian Pediatr 54(6): 481-488.

14. Millichap JG (2008) Etiologic classifcation of attention-defcit/ hyperactivity disorder. Pediatrics 121(2): e358-e365.

15. Mann JR, McDermott S (2011) Are maternal genitourinary infection and pre-eclampsia associated with ADHD in schoolaged children? Journal of Attention Disorders 15(8): 667-673.

16. Faraone S (2006) The Genetics of Attention-Deficit/Hyperactivity Disorder: Current Status and Clinical Implications. Medscape Psychiatry \& Mental Health 11(2).

17. Amiri S, Malek A, Sadegfard M, Abdi S (2012) Pregnancy related maternal risk factors of attention-defcit hyperactivity disorder: a CaseControl Study. ISRN Pediatrics Article ID 458064.

18. Malhi P, Singhi P (2013) Attention Deficit Hyperactivity disorder in Children. Pediatric Neurology. Gupta BD, Maheshwari RK, Parakh M, Purohit A, Kumar M (Eds.), Recent Trends in Pediatrics-Pediatric Neurology. Raj Pedicon, Barmer, India, pp. 58-74.

19. American Psychiatric Association (2013) Diagnostic and Statistical Manual of Mental Disorders. (5 ${ }^{\text {th }}$ edn). American Psychiatric Association, Arlington VA, USA.

20. Baumgaertel A, Wolraich ML, Dietrich M (1995) Comparison of diagnostic criteria for attention deficit disorders in a German elementary school sample. J Am Acad Child Adolesc Psychiatry 34(5): 629-638.

21. Spencer T, Biederman J, Coffey B, Geller D, Wilens T, et al. (1999) The 4-year course of tic disorders in boys with attention-deficit/ hyperactivity disorder. Arch Gen Psychiatry 56(9): 842-847.

22. James Haggerty. Treatment of ADHD in children.

23. Prince JB, Wilens TE (2009) Pharmacotherapy of ADHD and Comorbidities, in ADHD Comorbidities: Handbook for ADHD Complications in Children and Adults, First Edition. Edited by Brown TE. Washington DC, American Psychiatric Publishing, pp. 339-384.

24. Department of Education 2001. Educational White Paper 6: Special needs education (Building an Inclusive Education and Training System). Pretoria: DoE.

25. Kara Tamanini. Setting Up a Behavior Management Plan for an ADHD Child.

26. Behaviour therapy for young children with ADHD. 
Your next submission with Juniper Publishers will reach you the below assets

- Quality Editorial service

- Swift Peer Review

- Reprints availability

- E-prints Service

- Manuscript Podcast for convenient understanding

- Global attainment for your research

- Manuscript accessibility in different formats

( Pdf, E-pub, Full Text, Audio)

- Unceasing customer service

Track the below URL for one-step submission https://juniperpublishers.com/online-submission.php 